\title{
Meningkatkan Motivasi Belajar Kimia Melalui Implementasi Konsep Kimia dalam Bentuk Permainan Sederhana di SMAN 4 Praya
}

\author{
Eka Junaidi $^{1 *}$, Aliefman Hakim¹, Saprizal Hadisaputra', Yunita Arian Sani Anwar ${ }^{1}$, Baiq Fara \\ Dwirani Sofia ${ }^{1}$ \\ ${ }^{I}$ Program Studi Pendidikan Kimia, FKIP, Universitas Mataram, Mataram Indonesia
}

\section{DOI: https://doi.org/10.29303/jpmsi.v3i2.134}

Citation: Junaidi, E., Hakim, A., Hadisaputra, S., Anwar, Y, A, S., Sofia, B, F, D. 2021. Meningkatkan Motivasi Belajar Kimia Melalui Implementasi Konsep Kimia dalam Bentuk Permainan Sederhana di SMAN 4 Praya. Jurnal Pengabdian Masyarakat Sains Indonesia (JPMSI). 3(2):240-245.

\author{
Article history \\ Received: July $25^{\text {th }} 2021$ \\ Revised: September $16^{\text {th }} 2021$ \\ Accepted: October $31^{\text {th }} 2021$ \\ *Corresponding Author: Eka \\ Junaidi, Study Program of \\ Chemistry Education, \\ University of Mataram, \\ Mataram, Indonesia \\ Email: ekajuned@unram.ac.id
}

\begin{abstract}
Abstrak: Pengabdian ini bertujuan untuk meningkatkan motivasi belajar kimia melalui implementasi konsep kimia dalam bentuk permainan sederhana. Kegiatan ini dilaksanakan di SMAN 4 Praya. Melalui kegiatan ini diharapkan anggapan siswa pada mata pelajaran kimia yang termasuk pelajaran yang sulit, membosankan, menakutkan dapat diubah menjadi pelajaran yang disukai, menyenangkan sehingga motivasi belajar kimia dapat ditingkatkan sebagai bagian dari upaya peningkatan hasil belajarnya. Metode pelaksanaan pengabdian yang semula akan dilaksanakan secara luring tetapi karena pelaksanaannya dilaksanakan saat pandemi sehingga pelaksanaan kegiatan dimodifikasi menjadi daring dengan pembuatan video implementasi konsep kimia dalam bentuk permainan sederhana. Adapun tahapan yang dilakukan dalam kegiatan pengabdian ini diantaranya : 1). Pembuatan Video praktikum sederhana dengan menampilkan beberapa implementasi konsep kimia sederhana. 2). Penyebaran angket quisioner motivasi belajar terutama ditujukan bagi peserta pengabdian setelah menyaksikan video praktikum sederhana. 3). Tahap analisa hasil respon siswa untuk mengetahui tingkat motivasi siswa dalam pembelajaran kimia meskipun pelaksanaan pembelajaran dilakukan secara daring. Kegiatan ini dilaksanakan pada hari Jum'at tanggal 18 September 2020, yang diikuti oleh Siswa SMAN 4 Praya yang terdiri atas perwakilan kelas XI IPA 3 (sebanyak 20 siswa) dan Kelas XI IPA 6 (sebanyak 22 siswa) sehingga total peserta sebanyak 42 siswa. Berdasarkan hasil tanggapan siswa diperoleh informasi : 1). Sebanyak 95,2 \% (40 siswa) menyatakan bahwa kimia adalah mata pelajaran yang menyenangkan, 2). Sebanyak 95,2\% (40 siswa) menyatakan pelajaran kimia akan menarik jika dilakukan praktikum di laboratorium, serta c). Sebanyak 97,6\% (41 siswa) menyatakan bahwa demonstrasi kimia meningkatkan motivasi belajar kimia. Dengan demikian adanya implementasi konsep kimia dalam bentuk permainan sederhana ini diharapkan mampu meningkatkan motivasi belajar kimia sekaligus merubah cara pandang siswa terhadap kimia menjadi pelajaran yang mudah, menarik, menyenangkan dapat tercapai serta harapan dan tujuan dari kegiatan pengabdian di SMAN 4 Praya dapat tercapai.
\end{abstract}

Kata kunci: Implementasi, Konsep Kimia, Permainan Sederhana, Motivasi

\section{Pendahuluan}

Pelajaran kimia seringkali dianggap oleh sebagian besar siswa SMA sebagai salah satu mata pelajaran yang relatif sulit, bersifat abstrak dan memiliki kecendrungan tidak disukai oleh siswa.
Berdasarkan hasil observasi pada beberapa siswa, alasan ketidaksukaan itu disebabkan karena materi kimianya sendiri dan sebagian lagi disebabkan oleh metode pembelajaran yang dilakukan oleh guru kurang bervariatif, tidak menarik dan cenderung membosankan. Ditambah lagi dengan kondisi yang 
Junaidi et al, Jurnal Pengabdian Masyarakat Sains Indonesia 2021, 3 (2):240-245 DOI: https://doi.org/10.29303/ipmsi.v3i2.134

dihadapi pada saat pandemic Covid 19, dimana pembelajaran harus dilakukan secara daring sehingga kesempatan berinteraksi langsung dengan guru di kelas tidak akan optimal, ditambah lagi terkait masalah non teknis seperti sinyal, quota dan perangkat pembelajaran yang digunakan saat belajar tidak bisa maksimal. Tentu saja kondisi ini akan menambah masalahan yang dihadapi oleh siswa saat pembelajaran. Kondisi-kondisi ini menjadi satu tantangan tambahan bagi guru dalam membelajarkan kimia. Belum lagi jika guru, maupun sekolah belum siap dalam menghadapi situasi pembelajaran online. Dengan demikian pembelajaran kimia akan bertambah sulit bukan hanya karena alasan materi pelajarannya tetapi juga karena masalah non teknis pembelajaran yang dilakukan secara daring.

Kompleksitas masalah tersebut tidak jarang membuat siswa acuh tak acuh terhadap mata pelajaran kimia. Untuk mendorong minat dan motivasi belajar kimia para siswa, selain mengaitkan pelajaran kimia dengan aspek praktis sehari-hari, penggunaan analogi-analogi konsep abstrak dengan kehidupan sehari-hari akan sangat membantu siswa dalam memahami pelajaran kimia (Ashadi, 2009).

Selain itu upaya yang juga dapat dilakukan oleh guru kimia selain menggunakan metode pembelajaran yang tepat adalah alternatif pendekatan pembelajaran lainnya seperti kegiatan permainan kimia sederhana. Pendekatan konsep kimia melalui permainan dianggap akan lebih memudahkan siswa dalam menghubungkan konsep kimia yang ada dengan permainan yang telah mereka lakukan atau saksikan. Hal ini dimaksudkan agar kesan abstrak dan rumit serta tidak dapat ditemui dalam kehidupan sehari - hari yang diasumsikan oleh siswa terhadap pelajaran ilmu kimia dapat dihilangkan. Sedangkan untuk mengatasi permasalah terkait kondisi pembelajaran pada saat pandemi (pembelajaran daring), guru dapat menyesuaikan bentuk-bentuk pembelajaran berupa praktikum sederhana dalam bentuk video. Keuntungan yang diperoleh oleh siswa dengan bentuk praktikum seperti ini adalah siswa dapat memutar ulang video yang diberikan berkali-kali jika mereka merasa belum mampu mencerna makna yang diperoleh melalui video yang dibuat.

Meskipun kegiatan tersebut sangat sederhana namun tetap saja peran serta guru kimia sebagai pembina mata pelajaran kimia akan sangat berperan dalam menentukan keberhasilan proses
e-ISSN $\cdot 2715-2537$

p-ISSN : 2715-2545

pembelajaran kimia. Kemampuan guru kimia yang mumpuni akan menghasilkan kinerja yang optimal saat pembelajaran.

Semua aspek yang terkait dalam pembelajaran akan dioptimalkan oleh guru yang kreatif dan inovatif sehingga kegiatan pembelajaran tidak menoton dan membosankan. Hal ini juga merupakan salah satu tuntutan keprofesionalan seorang guru kimia sesuai dengan kompetensi pedagogik yang harus dikuasai oleh guru kimia. Seorang guru dituntut untuk dapat menyajikan materi pembelajaran dengan berbagai pendekatan dan strategi yang kesemuanya diharapkan mampu membuat peserta didik menjadi lebih aktif. Oleh karena itu, guru harus kreatif dan inovatif menciptakan berbagai kegiatan yang tidak hanya dilakukan di dalam kelas, tetapi juga di luar kelas.

Menurut Hansen \& Lovedahl (2004) "belajar dengan melakukan" merupakan sarana belajar yang efektif, artinya seseorang akan belajar efektif bila ia melakukan. Hal ini sesuai dengan yang diharapkan kurikulum 2013 bahwa pembelajaran lebih ditekankan menggunakan metode pembelajaran scientifik, dengan demikian guru nantinya hanya akan menjadi fasilitator pembelajaran di kelas, sedangkan pembelajarannya akan berpusat pada siswa.

Berdasarkan kondisi tersebut Program studi Kimia FKIP Unram sebagai salah satu instansi lembaga pendidikan penghasil guru kimia, ingin mengambil peran dan berinisiatif mengadakan pengabdian pada masyarakat sebagai salah satu bagian tridarma perguruan tinggi dengan judul 'Implementasi Konsep Kimia Dalam Bentuk Permainan Sederhana Untuk Meningkatkan Motivasi Belajar Kimia di SMAN 4 Praya Lombok Tengah'.

Adanya kegiatan tersebut diharapakan mampu meningkatkan motivasi siswa dalam belajar kimia serta merubah cara pandangnya terhadap pelajaran kimia menjadi pelajaran yang mudah, menarik, dan menyenangkan serta hadir dalam kehidupan kesehariannya, baik dalam lingkup akademik maupun dalam kehidupan mereka bermasyarakat secara umum. Oleh karena situasi yang dihadapi sekolah adalah pembelajaran daring, maka bentuk kegiatan yang dilakukan juga mengalami penyesuaian-penyesuaian yakni dikemas dalam bentuk video permainan sederhana sebagai bagian dari memunculkan kreatifitas pembelajaran pada masa pandemic. 
Junaidi et al, Jurnal Pengabdian Masyarakat Sains Indonesia 2021, 3 (2):240-245 DOI: https://doi.org/10.29303/ipmsi.v3i2.134

\section{Metode}

Metode pelaksanaan yang dilakukan dalam kegiatan pengabdian ini melalui serangkaian kegiatan yang dilaksanakan di SMAN 4 Praya Lombok Tengah, diantaranya : 1). Tahap persiapan yang terdiri atas koordinasi dengan pihak sekolah (guru mata pelajaran kimia). Selain itu sebagai tahap awal kegiatan ini, tim pengabdian mempersiapkan video-video permainan sederhana yang memiliki konsep kimia sebagai upaya merealisasikan tujuan kegiatan ini; 2). Tahap Pelaksanaan kegiatan pengabdian berupa pengiriman video-video yang sudah dibuat untuk di tonton oleh peserta didik yang dilanjutkan dengan pengisian quisioner motivasi belajar yang sudah disiapkan tim pengabdian; 3). Tahap Analisa data hasil respon siswa setelah selesai pengisian instrumen quisioner motivasi; 4). Tahap pelaporan yang merupakan bagian akhir kegiatan yang berisi informasi keterkaitan antara tingkat motivasi belajar siswa setelah menonton video-video permainan kimia sederhana.

\section{Hasil dan Pembahasan}

Secara keseluruhan kegiatan ini dapat dikatakan berhasil. Pertama karena peserta yang memberi respon sebanyak 42 orang siswa (Berdasarkan daftar responden) yang terdiri atas 20 orang siswa kelas XI IPA 3 dan 22 orang siswa kelas XI IPA 6. Alasan kedua adalah dapat terlihat dari sikap antusias yang ditunjukkan siswa saat mengirimkan hasil responden angket quisioner (sekitar 2 hari) dengan mengikuti setiap tahapan kegiatan yang dilakukan dalam kegiatan pengabdian.

Berdasarkan serangkaian tahapan yang telah dilaksanakan dalam pengabdian ini diperoleh beberapa informasi terkait dengan hasil pengabdian masyarakat diantaranya :

1. Pembuatan video permainan sederhana. Pada kegiatan ini dibuat 5 buah video diantaranya :

\section{a. Reaksi Kimia.}

Pada video ini ditunjukkan beberapa contoh reaksi kimia sederhana antara lain reaksi antara Fenoftalen dan $\mathrm{KOH}$ yang keduanya berwarna bening, setelah kedua bahan dicampur kemudian akan terjadi perubahan warna menjadi warna Pink. Konsep adanya perubahan warna setelah dicampur mengindikasikan bahwa pada campuran tersebut telah terjadi
e-ISSN : 2715-2537

p-ISSN : 2715-2545

reaksi kimia yang ditunjukkan dengan produk hasil reaksinya yang berwarna Pink. Hal ini dapat terjadi karena senyawa kimia memiliki kemampuan untuk menyerap warna dan memancarkan warna. Dengan demikian konsep kimia yang ditawarkan melalui video ini adalah perubahan warna sebagai penanda terjadinya reaksi kimia.

\section{b. Pembuatan Larutan.}

Pada video ini akan dibuat larutan $\mathrm{NaCl} 0,5$

M. Sebagaimana diketahui bahwa $\mathrm{NaCl}$ merupakan senyawa yang banyak digunakan dirumah, dengan adanya video ini, peserta didik tidak beranggapan bahwa bahan yang digunakan untuk membuat larutan hanya ada di laboratorium, akan tetapi banyak bahan kimia yang juga dapat ditemukan di lingkungan sekitar. Sedangkan proses atau tahapan pembuatan larutan bisa dilihat berdasarkan informasi yang diberikan dalam video. Setelah selesai pembuatan larutan pertama (larutan 1), kemudian dibuat kembali dengan cara yang sama untuk larutan $\mathrm{NaCl}$ pada konsentrasi berbeda (larutan 2). Untuk mempelajari konsep konsentrasi, (yang lebih tinggi dan lebih rendah) pembuktiannya bisa dilakukan dengan cara mencicip larutan yang telah dibuat kemudian menentukan larutan mana yang lebih asin. Tingkat keasinan ini juga menunjukkan tingkat konsentrasi yang dimiliki oleh larutan $\mathrm{NaCl}$ tersebut. jadi berdasarkan konsep ini peserta didik juga akan dapat menguasai konsep konsentrasi yang dimiliki oleh larutan.

\section{c. Pengenceran.}

Pada Video ini ditunjukkan konsep pengenceran pada sirup yang digunakan sebagai bahan untuk mempelajari materi pengenceran. Merdasarkan video yang diperoleh, pada keadaan awal sebelum di encerkan (penambahan Air) pada sirup terasa lebih kecut, namun setelah ditambahkan air pada sirup, komposisi sirup menjadi lebih encer sehingga pada saat pencicipan kembali sirup terasa lebih manis. Pada video ini, konsep yang ingin ditampilkan bahwa konsentrasi suatu larutan yang pekat jika ditambahkan pelarut akan diperoleh konsentrasi yang lebih encer.

\section{d. Laju Reaksi.}

Pada video ini ditunjukkan salah satu faktor yang mempengaruhi laju reaksi adalah 
Junaidi et al, Jurnal Pengabdian Masyarakat Sains Indonesia 2021, 3 (2):240-245 DOI: https://doi.org/10.29303/ipmsi.v3i2.134

konsentrasi zat yang bereaksi. Pada video tersebut terlihat pita $\mathrm{Mg}$ yang memiliki ukuran tetap dicelupkan pada larutan $\mathrm{HCl}$ yang berbeda konsentrasi. Berdasarkan pengamatan dari video tersebut diperoleh bahwa pita $\mathrm{Mg}$ yang dicelupkan pada $\mathrm{HCl}$ yang memiliki konsentrasi paling tinggi akan memiliki waktu melarutkan pita $\mathrm{Mg}$ yang paling kecil jika dibandingkan dengan pita $\mathrm{Mg}$ yang dilarutkan pada $\mathrm{HCl}$ yang konsentrasinya sedikit lebih encer. Berdasarkan hasil pengamatan video tersebut dapat disimpulkan bahwa semakin tinggi konsentrasi suatu zat, maka laju reaksinya juga akan semakin cepat.

\section{e. Air Ajaib.}

Pada video ini akan didemonstrasikan pembuatan air ajaib. Air ajaib ini terbuat dari Aquades, glukosa, $\mathrm{KOH}$ dan indicator metilen blue. Setelah semua bahan dicampur, kemudian botol yang berisi material tadi dikocok dengan cepat sampai terjadi perubahan warna dari sebelumnya berwarna bening menjadi warna biru. setelah didiamkan beberapa saat, larutan yang semula berwarna biru akan berubah menjadi bening kembali. Adapun konsep yang diperoleh dari percobaan ini adalah konsep kesetimbangan larutan.

2. Analisa data hasil tanggapan yang diberikan siswa setelah menonton video untuk dikorelasikan dengan motivasi belajar siswa.

Berdasarkan analisa data hasil tanggapan yang diberikan siswa setelah dilakukan kegiatan ini, setiap item butir pertanyaan kemudian diklasifikasikan menjadi 3 kelompok sikap siswa terhadap apa yang mereka berikan tanggapan diantaranya :

a. Sikap siswa terhadap mata pelajaran kimia

Berdasarkan tanggapan siswa sebanyak 42 orang ketika diberikan pertanyaan 'kimia adalah mata pelajaran yang menyenangkan' diperoleh data bahwa $35,7 \%$ sangat setuju dengan pernyataan itu, 59,5\% menyatakan setuju sedangkan sisanya $4,8 \%$ ragu-ragu. Berdasarkan data tersebut dapat disimpulkan bahwa 95,2 \% (40 orang) menyatakan bahwa kimia adalah mata pelajaran yang menyenangkan.

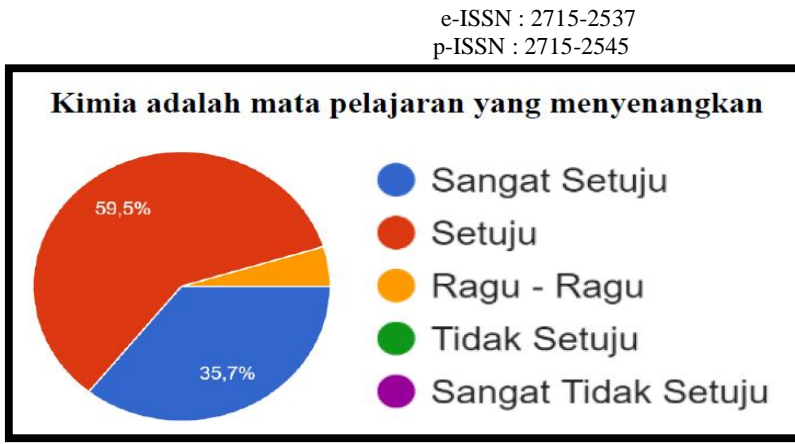

Gambar 1. Respon Sikap Siswa terhadap mata pelajaran Kimia

\section{b. Sikap Siswa terhadap praktikum kimia}

Berdasarkan tanggapan siswa sebanyak 42 orang ketika diberikan pertanyaan 'Praktikum di laboratorium merupakan kegiatan yang menarik saat belajar kimia' diperoleh data bahwa 45,2\% sangat setuju dengan pernyataan itu, 50,0\% menyatakan setuju, ragu-ragu 2,4 \% (1 orang) dan tidak setuju 2,4\% (1 orang). Berdasarkan data tersebut dapat disimpulkan bahwa 95,2\% (40 orang) menyatakan pelajaran kimia akan menarik jika dilakukan praktikum di laboratorium.

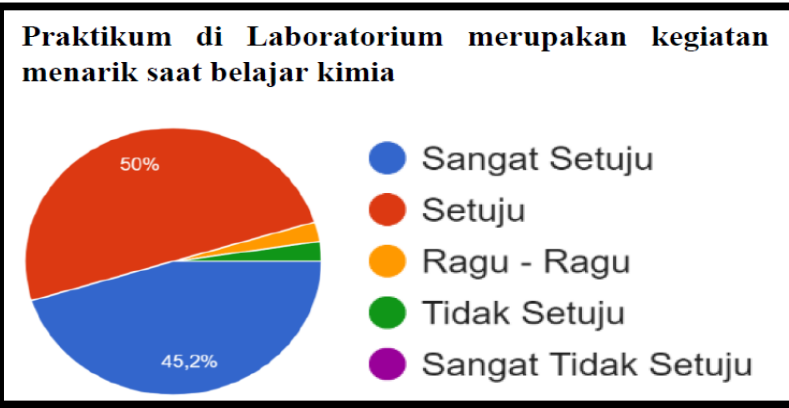

Gambar 2. Respon Sikap Siswa terhadap praktikum Kimia

\section{c. Sikap siswa terhadap demonstrasi kimia}

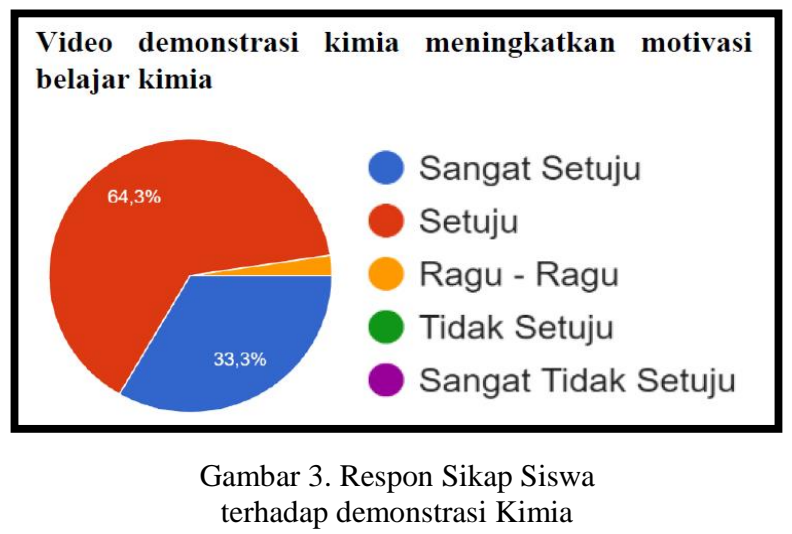


Junaidi et al, Jurnal Pengabdian Masyarakat Sains Indonesia 2021, 3 (2):240-245 DOI: https://doi.org/10.29303/ipmsi.v3i2.134

Berdasarkan tanggapan siswa sebanyak 42 orang ketika diberikan pertanyaan 'Video Demonstrasi kimia meningkatkan motivasi saya belajar kimia'diperoleh data bahwa 33,3\% sangat setuju dengan pernyataan itu, $64,3 \%$ menyatakan setuju sedangkan sisanya $2,4 \%$ (1 orang) ragu-ragu. Berdasarkan data tersebut dapat disimpulkan bahwa 97,6\% (41 orang) menyatakan bahwa demonstrasi kimia meningkatkan motivasi belajar kimia.

Dengan demikian berdasarkan data-data tanggapan siswa tersebut dapat disimpulkan bahwa meningkatnya motivasi siswa akan dipengaruhi oleh perasaan tertarik terhadap pelajarannya kemudian konsep pelajaran tersebut dapat di implementasikan (dipraktekkan) dalam bentuk permainan sederhana yang pada gilirannya kedua hal tersebut akan meningkatkan motivasi belajar siswa pada mata pelajaran kimia sebagaimana yang diperoleh informasi berdasarkan hasil quisioner yang telah disebarkan pada siswa SMAN 4 Praya.

\subsection{Faktor Pendorong}

Pada kegiatan ini terdapat faktor pendorong yang menyebabkan pentingnya kegiatan ini untuk dilaksanakan yaitu masih minimnya pemanfaatan laboratorium sebagai media dalam proses belajar mengajar ilmu kimia (ranah Kognitif), sikap-sikap yang harus dilakukan dalam mengelola laboratorium (ranah Afektif) serta langkah-langkah yang harus diperhatikan/dilakukan pada saat demostrasi kimia (ranah Psikomotorik). Hal ini sangat penting diketahui siswa oleh karena laboratorium adalah suatu media yang dapat menjembatani teori yang diajarkan guru di dalam kelas untuk dipraktekkan di laboratorium, atau menggunakan media lain seperti video praktikum sederhana (demonstrasi kimia) yang disesuaikan dengan kondisi sekolah pada saat pandemi covid19. Selain itu SMAN 4 Praya Lombok Tengah juga termasuk salah satu sekolah yang memiliki fasilitas alat laboratorium kimia yang cukup memadai. Hal ini dapat dilihat dari banyak alat-alat gelas yang masih belum digunakan seperti beker, erlenmeyer, buret, pipet gondok, labu pengenceran dan sebagainya.

\subsection{Faktor Penghambat}

Peserta yang turut berpartisipasi dalam kegiatan ini adalah kelas XI IPA 3 dan XI IPA 6 masih memiliki tingkat pengetahuan yang berbeda-

$$
\begin{array}{r}
\text { e-ISSN : 2715-2537 } \\
\text { p-ISSN : 2715-2545 }
\end{array}
$$

beda tentang alat dan bahan kimia termasuk teoriteori yang sudah diperoleh dari guru hal ini menyebabkan penjelasan yang diberikan harus dengan analogi-analogi sederhana yang dekat dengan kehidupan mereka sehari-hari guna menjembatani adanya perbedaan pengetahuan yang dimiliki setiap siswa tanpa mengurangi makna/prinsip dasar dari teori-teori dalam ilmu kimia. Kendala lain yang dihadapi adalah karena pembelajaran pada masa pandemi covid-19 menyebabkan pembelajaran dilaksanakan secara online sehingga masalah yang muncul juga terkait dengan kendala non teknis seperti sinyal dan kuota saat pelaksanaan kegiatan.

\section{Kesimpulan}

Berdasarkan hasil evaluasi terhadap pelaksanaan kegiatan pengabdian ini maka dapat disimpulkan sebagai berikut :

1. Kegiatan pengabdian ini dapat dinyatakan sangat berhasil mengingat dari keseluruhan peserta sebanya 42 orang yang dijadikan responden semuanya memberikan tanggapan. Berdasarkan hasil tanggapan siswa diperoleh informasi bahwa : a). Sebanyak 95,2 \% (40 orang) menyatakan bahwa kimia adalah mata pelajaran yang menyenangkan, b). Sebanyak 95,2\% (40 orang) menyatakan pelajaran kimia akan menarik jika dilakukan praktikum di laboratorium, serta c). Sebanyak 97,6\% (41 orang) menyatakan bahwa demonstrasi kimia meningkatkan motivasi belajar kimia.

Dengan demikian kegiatan dapat dinyatakan berhasil untuk meningkatkan motivasi belajar kimia siswa SMAN 4 Praya Lombok Tengah.

2. Pengabdian ini sangat bermanfaat tidak hanya bagi siswa tapi bagi guru pembina maupun sekolah. Karena adanya kegiatan semacam ini dapat menambah wawasan keilmuwan dan keterampilan bagi guru. Sedangkan bagi sekolah semakin tinggi minat belajar siswa diharapkan akan memberikan korelasi positif pada peningkatan prestasi belajar siswa. Dengan demikian kegiatan ini diharapkan mampu mendukung pembelajaran kimia dilakukan secara terintegrasi baik di kelas maupun di laboratorium dalam situasi pembelajaran luring maupun pembelajaran daring 
Junaidi et al, Jurnal Pengabdian Masyarakat Sains Indonesia 2021, 3 (2):240-245 DOI: https://doi.org/10.29303/ipmsi.v3i2.134

Saran

Perlu dilakukan pengabdian lanjutan dengan topik yang bervariatif dalam upaya meningkatkan wawasan serta pengetahuan siswa serta melakukan kegiatan pada saat kegiatan proses belajar mengajar sedang tidak aktif untuk menghindari terganggunya kegiatan belajar yang sudah dirancang dengan baik.

\section{Ucapan Terima Kasih}

Penulis mengucapkan terima kasih kepada Universitas Mataram yang telah menfasilitasi kegiatan pengabdian ini. Kemudian termakasih pula peulis sampaikan kepada Kepala Sekolah, Guru serta Siswa SMAN 4 Praya yang telah mendukung kegiatan ini sehingga berjalan dengan baik.

\section{Daftar Pustaka}

Adijuwana Hendra, 1992, Manajemen Laboratorium, Istitut Pertanian Bogor, Bogor.

Ashadi, 2009, Kesulitan belajar kimia bagi siswa sekolah menengah, https://library.uns.ac.id/kesulitan

belajar kimia bagi siswa sekolah menengah di download tanggal 24 Februari 2020

Budiono Djoko, 1992, Pengantar Kegiatan Laboratorium Biologi, University Press IKIP Surabaya. https://saintif.com/reaksi-kimia/ (di unduh tanggal 29 Nov 2020)

Junaidi, E, dkk 2019, Upaya Meningkatkan Motivasi Siswa SMA Masuk Program

Studi Pendidikan Kimia FKIP

Unram Melalui Pengenalan Praktikum

Kimia Sederhana Di SMAN 1

Pringgarata, Laporan Pengabdian PNBP 2019

John W. Hansen \& Gerald G. L.. (2004). Developing technology teachers : questioning the industrial tool use model. Journal of Technology Education. $15(2), 20-32$.

Mulyono, 2006, Membuat Reagen Kimia, Bumi Aksara, Jakarta.

Padmawinata Djupri, dkk., 1983, Pengelolaan Laboratorium IPA, Dirjen

Dikti, Jakarta. $\begin{array}{ccc} & & \text { e-ISSN : } 2715-2537 \\ \text { p-lISSN : 2715-2545 } & \\ \text { Sudarmadji } \quad \text { Slamet, } \quad \text { dkk., } 1984, \quad \text { Prosedur }\end{array}$ Analisa untuk Bahan Makanan dan Pertanian, Liberty, Yogyakarta.

Tim, 2002, Pedoman Standar Minimal Pendayagunaan Peralatan Laboratorium Kimia, Direktorat Pendidikan Menengah Umum, Jakarta.

Tim, 2004, Penanganan Bahan - bahan Kimia Berbahaya dan Beracun Serta keselamatan Kerja, Pusat Penelitian Kimia, Bandung.

Wulanningtyas, N, D, 2018, Belajar Kimia sambil Bermain, http://jatengpos.co.id/belajar-kimiasambil- bermain/

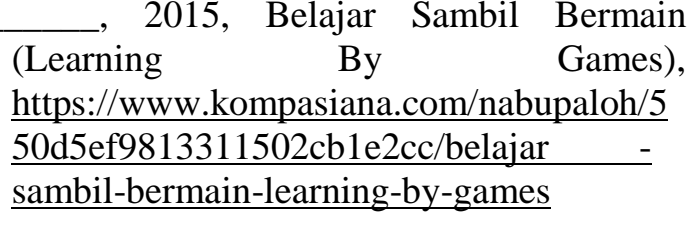

